\title{
Health Risk Assessment of Natural Radioactivity in Wasteland Soils in Okakarara, Namibia
}

\author{
S.A. Onjefu ${ }^{*}$, C. Kamunda ${ }^{2}$ and J. Abah $^{3}$ \\ ${ }^{(1)}$ Department of Natural and Applied Sciences, Faculty of Health and Applied Sciences, Namibia University of Science and \\ technology, Windhoek, Namibia. \\ ${ }^{(2)}$ Copperbelt University, School of Mathematics and Natural Sciences, Department of Physics, Zambia \\ (3) Department of Mathematics, Science and Sport Education, Faculty of Education, University of Namibia, Katima Mulilo \\ Campus, Namibia
}

\begin{tabular}{l} 
ART ICLE IN FO \\
\hline Article history: \\
Received: $12^{\text {th }}$ Oct. 2020 \\
Accepted: $22^{\text {nd }}$ Mar. 2021 \\
\hline Keywords: \\
Gamma-ray Spectrometry, \\
Cancer risk, \\
Hazard Index, Wasteland, \\
Soil, Radionuclides.
\end{tabular}

\begin{abstract}
Human activities such as waste disposal tend to impact negatively on the environment. Some waste products are associated with elevated levels of natural radioactivity. It was therefore, the aim of the study to investigate the health risk associated with natural radioactivity from Okakarara municipal waste dumpsite. In this study, gamma spectrometric analysis was used to determine the activity concentrations of ${ }^{226} \mathrm{Ra},{ }^{232} \mathrm{Th}$ and ${ }^{40} \mathrm{~K}$ in 18 soil samples. From these activity concentrations, some radiological parameters were calculated. The average activity concentrations of ${ }^{226} \mathrm{Ra}$, ${ }^{232} \mathrm{Th}$ and ${ }^{40} \mathrm{~K}$ in $\left(\mathrm{Bq} \cdot \mathrm{kg}^{-1}\right)$ were $15.45 \pm 0.47,18.00 \pm 0.55$, and $215.73 \pm 4.29$, respectively. The average $R_{e q}$ value was $57.80 \pm 0.98 \mathrm{~Bq} \cdot \mathrm{kg}^{-1}$. In all the samples, $\mathrm{Ra}_{\mathrm{eq}}$ values were found to be lower than the worldwide value of $370 \mathrm{~Bq} \cdot \mathrm{kg}^{-1}$. The absorbed dose rate was found to be $27.00 \pm 0.44 \mathrm{nGy} \mathrm{h}^{-1}$, whereas an average value of $0.03 \mathrm{mSv} . \mathrm{y}^{-1}$ for AEDE was noted, which is less than $0.48 \mathrm{mSv}$, the worldwide average. The Annual Gonadal Dose Equivalent (AGDE) was $190.89 \mu \mathrm{Sv} \cdot \mathrm{y}^{-1}$, a value less than the world average of $298 \mu \mathrm{Sv} \cdot \mathrm{y}^{-1}$. The average values of the Representative Level Index (RLI) and the External Hazard Index $\left(\mathrm{H}_{\mathrm{ex}}\right)$ was found to be 0.43 and 0.16 ., respectively. These indices were less than unity. The average value of the excess lifetime cancer risk (ECLR) was $1.16 \times 10^{-4}$ ?? units. This value was lower than the internationally acceptable limit of $2.9 \times 10^{-4 ? ?}$. From these results it can be concluded that natural radioactivity from the wasteland area of Okakarara was not an issue of health concern.
\end{abstract}

\section{INTRODUCTION}

In 1896, A. H. Becquerel discovered radioactivity. Since then, several studies on radioactivity have been undertaken [1]. Radiation and radioactivity constitute a major part of human existence. This process is both statistical and natural that describes the change of unstable nuclei with a release of energy by parent nuclei into daughter nuclei which are more stable [2]. The energy released during the transformation process result in the emission of nuclear particles or waves in the form of beta particles, alpha particles and gamma rays. The emissions are referred to as ionizing radiations. [3]. Ionizing radiations are radiations that produces charge when the pass through biological matter. This ionizing property makes them hazardous to biological tissues.
As early as 1920 s to 1930 s, the radiological hazardous nature of ionizing radiation has been the subject of discussion amongst the science world [4]. Both empirical and epidemiological findings has pointed to the carcinogenic properties of radioactive materials. A study by United States Food and Drug Administration (USFDA) said that since the beginning of this century, there has been increased cases of bone sarcomas and other malignancies to individuals who had ingested radium paint [5]. In addition to skin cancer which was also prominent among early dentists and radiologists from exposure to radioactive materials. Also, those who survived the Hiroshima atomic bomb were reported to have suffered from leukaemia because of exposure to radiation above 100 rem [5]. 
The damage to biological cells from ionizing radiation are classified as short term or long term. The radioactive short-term effects could arise after short time exposure to radiation, while those of long-term effects only show up after many years [5]. After exposure, interaction of ionizing radiation with cells and tissues may lead to alterative processes in mitosis, destruction of chromosomal arrangement that may ultimately occasion the development of cancerous cells. The damage from this ionizing radiation can be temporary or life-long depending on the severity of the exposure. In some cases, the damaged cell and tissues may recover from the effects of radiation only when such exposure is of smaller magnitude [6]. If the exposure is on a large scale, it become important from the point of view of health physics because it carries more degree of harm.

Human exposure to naturally occurring radionuclides comes from either man-made or natural sources. Study have shown that about $80 \%$ of these ionizing radiations comes from natural background radiation, which include cosmic rays, radon gas and terrestrial radionuclides [7]. That which forms terrestrial radionuclides are series radionuclides of uranium-radium $\left({ }^{238} \mathrm{U}-{ }^{226} \mathrm{Ra}\right)$, Thorium $\left({ }^{232} \mathrm{Th}\right)$ together with non-series radionuclides of potassium $\left({ }^{40} \mathrm{~K}\right)$. The levels of ionizing radiations may be exacerbated by man-made activities. Human induced activities such as waste disposal tend to impact negatively on the environment and public health. Some waste products are radioactive in nature and may have originated from industrial activities. Wastes associated with these activities can enhance levels of natural radioactivity in the environment [8]. They pollute water resources, air, plants, animals and soil. Soil is one of the major recipients of these waste products and the main reservoir of these naturally occurring radionuclides. They are transferred to humans through a number of pathways such as ingestion, dermal contact and inhalation of radon gas [9]. Radionuclides may pose a long-term risk even in very low concentrations. This study is aimed at carrying out measurements of the activity concentrations of radionuclides from the wasteland soils of Okakarara. The activity concentrations were then used to carry out health risk assessment in terms of radium equivalent activity, absorbed dose rate in air, annual gonadal dose equivalent, the annual effective dose equivalent, and excess lifetime cancer risk. Other radiological parameters that were considered are gamma representative level index and external hazard index.

\section{Materials and Methods}

\section{The Study Area}

The research was carried out in January 2019 with samples collected from the Okakarara municipal waste dumpsite. The sampling waste dumpsite is located in the Okakarara Constituency (Figure 1). The town covers a land mass of $18,951 \mathrm{~km}^{2}$ and is inhabited by 21,000 people dominated by the livestock farming by Herero communities. The dumpsite is located at $20^{\circ} 35^{\prime} 9^{\prime \prime} \mathrm{S}$ latitude and $17^{\circ} 27^{\prime} 28^{\prime \prime} \mathrm{E}$ longitude. The perimeter fence around the dumpsite has being vandalised which has made scavenging in the dumpsite a common practice as shown in Figure 2.

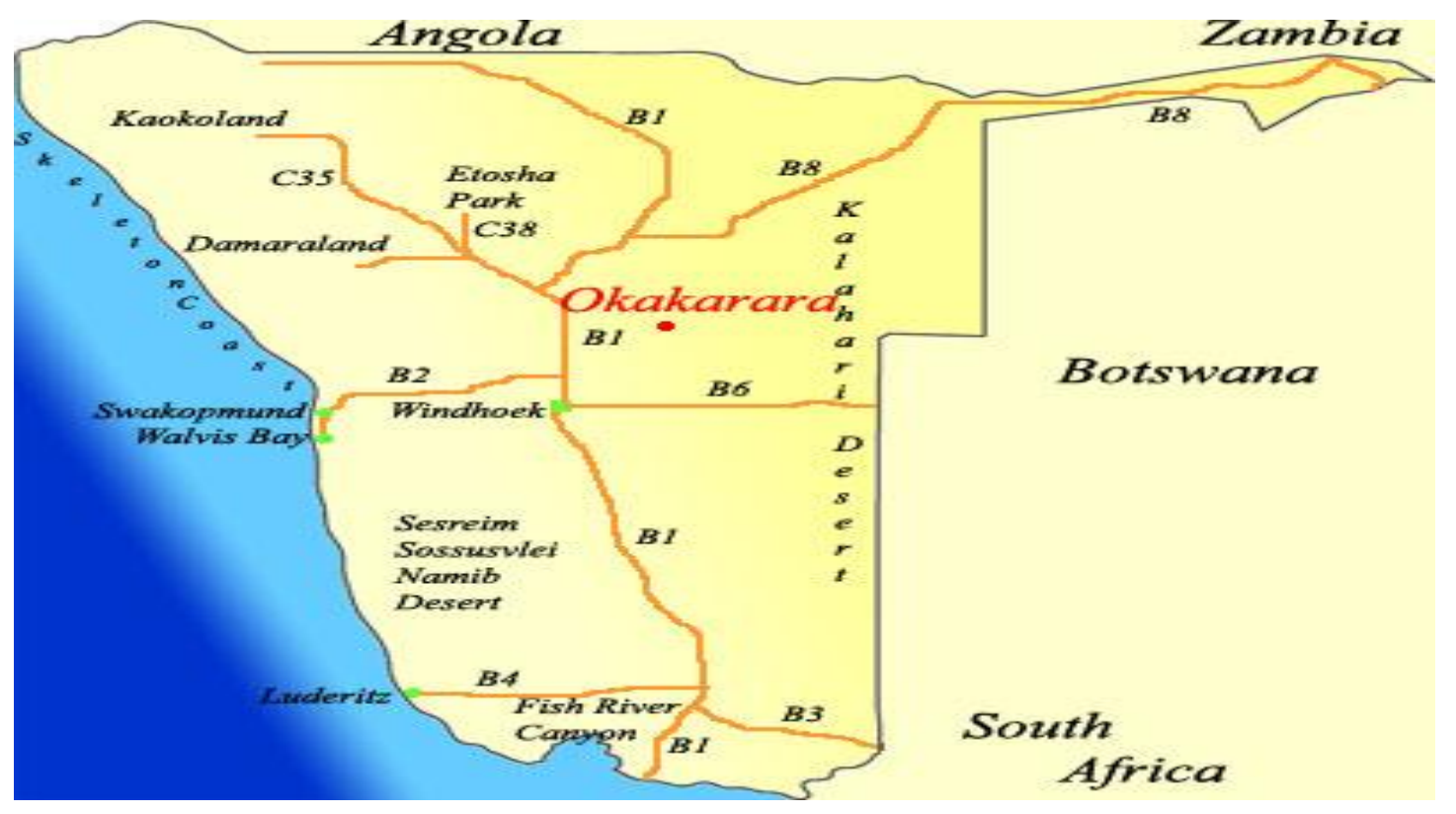

Fig. (1): Location map of Okakarara 


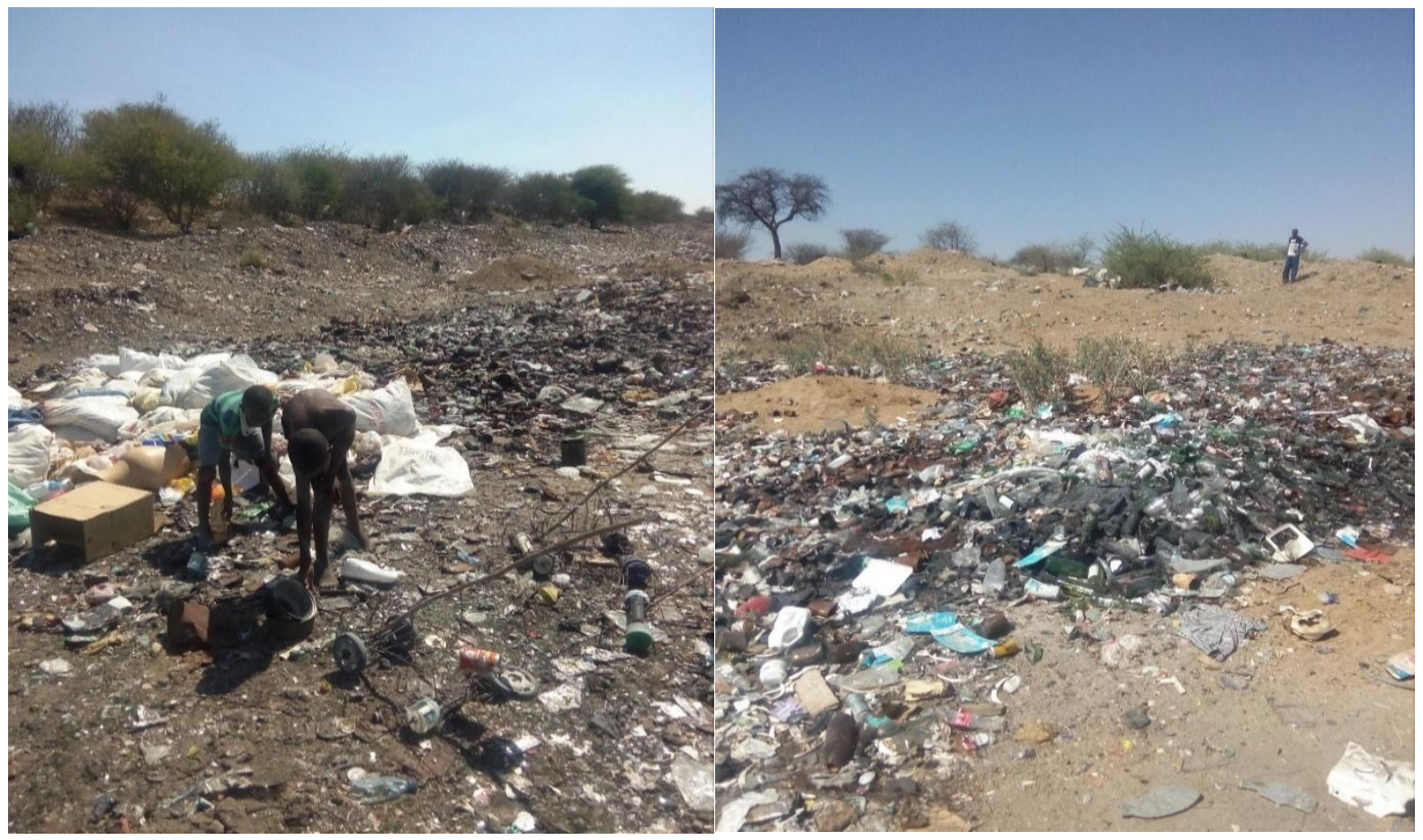

Fig. (2): Part of Okakarara dumpsite with Children scavenging

\section{Sample Collection and Preparation}

Eighteen samples of soil were collected from a depth of 20-50 cm with a soil auger from different locations in the waste dumpsite using purposive random sampling. The soil samples were pound and dried in the oven at $120^{\circ} \mathrm{C}$ to remove moisture. Each sample was then homogenized and sieved to about 200-mesh size. The samples weighing $1 \mathrm{~kg}$ were then put into a marinelli beaker and sealed for approximately 30 days to allow radioactive secular equilibrium to be attained between ${ }^{238} \mathrm{U},{ }^{232} \mathrm{Th}$ and their corresponding daughters [10].

\section{Gamma-ray Spectrometry}

The radioactivity in the collected soil samples was measured using a coaxial $(62.80$ X $64.80 \mathrm{~mm})$ Canberra gamma-ray spectrometer high purity germanium (HPGe) detector Model No. GC4520 SN 10882 with a resolution of $2.00 \mathrm{keV}$ full width at half maximum (FWHM) at $1.33 \mathrm{MeV}$ peak of ${ }^{60} \mathrm{Co}, 45 \%$ relative efficiency and $1.200 \mathrm{keV}$ (FWHM) at $122 \mathrm{keV}$. The detector is covered with lead shielding to reduce background radiation and cooled by liquid nitrogen. A computer-based software, Genie 2000 from Canberra was used for data acquisition and analysis. The samples were counted for $53200 \mathrm{~s}$ in a reproducible manner with the configuration and geometry maintained throughout the analysis. The gamma spectrometry system was energy and efficiency calibrated using gamma-ray energies between 0.060 $\mathrm{MeV}$ to $2 \mathrm{MeV}$ mixed radionuclides standard in a $500 \mathrm{ml}$
Marinelli beaker. The $295.22 \mathrm{keV}, 351.93 \mathrm{keV}$ for ${ }^{214} \mathrm{~Pb}$ and $609.32 \mathrm{keV}, 1120.29 \mathrm{keV}$ and $1764.49 \mathrm{keV}$ for ${ }^{214} \mathrm{Bi}$ gamma lines were used in the assessment of activity concentration of ${ }^{226} \mathrm{Ra}$, while $911.21 \mathrm{keV}$ for ${ }^{228} \mathrm{Ac}$ and $968.97 \mathrm{keV}$ and $238.63 \mathrm{keV}$ for ${ }^{212} \mathrm{~Pb}$ were used for ${ }^{232} \mathrm{Th}$. The isotope of ${ }^{40} \mathrm{~K}$ was obtained from the single $1460 \mathrm{keV}$ Gamma-line of ${ }^{40} \mathrm{~K}$.

\section{Risk Assessment of Radionuclides}

Risk assessment was done using the following radiological parameters; Radium Equivalent Activity $\left(\mathrm{Ra}_{\mathrm{eq}}\right)$, Annual Effective Dose Equivalent (AEDE), Absorbed Dose rate $\left(D_{R}\right)$, Annual Gonadal Dose Equivalent (AGDE), Representative Level Index (RLI), External Hazard Index $\left(\mathrm{H}_{\mathrm{ex}}\right)$ and Excess Lifetime Cancer Risk (ELCR).

\section{Radium Equivalent Activity $\left(\boldsymbol{R} \boldsymbol{a}_{\text {eq }}\right)$}

The natural radioactivity in soil, ${ }^{226} \mathrm{Ra},{ }^{232} \mathrm{Th}$ and ${ }^{40} \mathrm{~K}$ are not uniform in their distribution. To get uniformity with respect to radiation exposure, the Radium equivalent activity $\mathrm{Ra}_{\mathrm{eq}}$ is used [11]. It is the weighted sum of ${ }^{226} \mathrm{Ra},{ }^{232} \mathrm{Th}$ and ${ }^{40} \mathrm{~K}$ activity concentrations, which assumes that $370 \mathrm{~Bq} \cdot \mathrm{kg}^{-1}$ of ${ }^{226} \mathrm{Ra}$, $259 \mathrm{~Bq} \cdot \mathrm{kg}^{-1}$ of ${ }^{232} \mathrm{Th}$ and $4810 \mathrm{~Bq} \cdot \mathrm{kg}^{-1}$ of ${ }^{40} \mathrm{~K}$ produce the same dose rate. It can be calculated using Equation 2.

$$
\mathrm{Ra}_{\mathrm{eq}}=\left(\frac{\mathrm{AC}_{\mathrm{Ra}}}{370}+\frac{\mathrm{AC}_{\mathrm{Th}}}{259}+\frac{\mathrm{AC}_{\mathrm{K}}}{4810}\right) \times 370
$$

which is equivalent to 


$$
\mathrm{Ra}_{\mathrm{eq}}=\mathrm{AC}_{\mathrm{Ra}}+1.43 \mathrm{AC}_{\mathrm{Th}}+0.077 \mathrm{AC}_{\mathrm{K}}
$$

where $\mathrm{AC}_{\mathrm{Ra}}, \quad \mathrm{AC}_{\mathrm{Th}}$ and $\mathrm{AC}_{\mathrm{K}}$ are the activity concentrations in $\mathrm{Bq} \mathrm{kg}-1$ of ${ }^{226} \mathrm{Ra},{ }^{232} \mathrm{Th}$, and ${ }^{40} \mathrm{~K}$, respectively.

\section{Absorbed Dose Rate in Air $\left(D_{R}\right)$}

The absorbed dose rate depends on the specific activity of ${ }^{226} \mathrm{Ra},{ }^{232} \mathrm{Th}$ and ${ }^{40} \mathrm{~K}$ in soil with the assumption that other radioactive isotopes are negligible. Since contributions from these radionuclides are very small to the overall contribution to total background radiation [12]. The absorbed dose rate was calculated using the relation in equation 3 .

$\mathrm{D}_{\mathrm{R}}\left(\mathrm{nGy} \cdot \mathrm{h}^{-1}\right)=0.462 \mathrm{AC}_{\mathrm{Ra}}+0.604 \mathrm{AC}_{\mathrm{Th}}+0.0417 \mathrm{AC}_{\mathrm{K}}$

where $\mathrm{D}_{\mathrm{R}}$ is the absorbed dose rate, and $\mathrm{AC}_{\mathrm{Ra}}, \mathrm{AC}_{\mathrm{Th}}$ and $\mathrm{AC}_{\mathrm{K}}$ have the same meaning as in equation 2 .

\section{Annual Effective Dose Equivalent (AEDE)}

The annual effective dose equivalent was measured in unit of $\mathrm{mSv} y^{-1}$. This is the dose received by the general public from radioactivity concentrations in the soil and was calculated using equation 4 .

$\operatorname{AEDE}\left(\mathrm{mSv} \cdot \mathrm{y}^{-1}\right)=$

$\mathrm{D}\left(\mathrm{nGy} \cdot \mathrm{h}^{-1}\right) \times 8760(\mathrm{~h}) \times 0.2 \times 0.7\left(\mathrm{~Sv} . \mathrm{Gy}^{-1}\right) \times 10^{-6}$

Where $\mathrm{D}$ is absorbed dose rate $\left(n G y h^{-1}\right)$, and 0.7 $\mathrm{SvGy}^{-1}$ is the conversion coefficient from absorbed dose to effective dose. The number 0.2 represent the occupancy factor for outdoor [13], and 8760 hours is the time for one year while $10^{-6}$ is the conversion factor.

\section{Annual Gonadal Dose Equivalent (AGDE)}

According to UNSCEAR (2010) gonads are considered as organs of interest for dosimetry purposes. These are primary reproductive organs; testes in the male and the ovaries in the female. The International Commission for Radiation Protection [14] gave the number 0.2 as the Tissue Weighting Factor for Gonads. Because gonads are highly radio-sensitivity, every effort must be done to reduce gonadal dose to the general population. An elevation of the levels of AGDE is also known to affect the bone marrow that produces red blood cells. This may lead to cancer of the blood called leukaemia, which is often fatal. Other organs of interest are the thyroid, lungs, liver, colon, and bladder [15]. The annual gonadal dose equivalent (AGDE) in $\mu \mathrm{Sv}^{-1}{ }^{-1}$ is determined using the formula in Equation 5 [16]:

$\operatorname{AGDE}\left(\mu \mathrm{Sv} \cdot \mathrm{y}^{-1}\right)=3.09 \mathrm{AC}_{\mathrm{Ra}}+4.19 \mathrm{AC}_{\mathrm{Th}}+0.314 \mathrm{AC}_{\mathrm{K}}$ where $\mathrm{AC}_{\mathrm{Ra}}, \mathrm{AC}_{\mathrm{Th}}$ and $\mathrm{AC}_{\mathrm{K}}$ have the same meaning as in equation 2 .

\section{Representative Level Index (RLI)}

The gamma radioactivity Representative Level Index associated with naturally occurring radioactive elements and can be measured using the following formula [8]:

$$
R L I=\frac{1}{150} A C_{R a}+\frac{1}{100} A C_{T h}+\frac{1}{1500} A C_{K}
$$

The RLI values were calculated and the results shown in Table 3.

\section{External Hazard Index $\left(\mathrm{H}_{e x}\right)$}

Different radionuclides contribute to the total gamma dose received by man. To quantify radiological hazards as a single quantity, the hazard index is used [17]. The External hazards index was computed using the relation in equation 7 [13]. For radiological purposes, the $\mathrm{H}_{\mathrm{ex}}$ has to be less than one in order to keep exposure to radiation hazard negligible [18].

$$
\mathrm{H}_{\mathrm{ex}}=\left(\frac{A \mathrm{C}_{\mathrm{Ra}}}{370}+\frac{\mathrm{AC}_{\mathrm{Th}}}{259}+\frac{\mathrm{AC}_{\mathrm{K}}}{4810}\right) \leq 1
$$

\section{Excess Lifetime Cancer Risk (ELCR)}

The excess lifetime cancer risk (ELCR) for outdoor exposure, gives the probability for an individual to develop cancer over a lifetime at a given exposure. The ELCR was estimated using the assumption that there is a linear relationship between dose and the corresponding stochastic effects. This was calculated using equation 8 .

$$
\mathrm{ELCR}=\mathrm{AEDE} \times \mathrm{DL} \times \mathrm{RF}
$$

where AEDE, DL and RF are the Annual Effective Dose Equivalent, Duration of Life (70 years) and RF is the risk factor $\left(\mathrm{Sv}^{-1}\right)$. The International Commission on Radiological Protection (ICRP) employed the value 0.05 for stochastic effects for the public [19].

\section{RESULTS AND DISCUSSIONS}

Activity concentrations of ${ }^{226} \mathrm{Ra},{ }^{232} \mathrm{Th}$ and ${ }^{40} \mathrm{~K}$ analyzed from the soil in the dumpsite are presented in Table 1. Also presented in Table 1 are the results of the Radium Equivalent Activity $\left(\mathrm{Ra}_{\mathrm{eq}}\right)$ together with the Absorbed Dose Rate in Air $\left(D_{R}\right)$.

The average activity concentrations in $\left(\mathrm{Bq} \cdot \mathrm{kg}^{-1}\right)$ of ${ }^{226} \mathrm{Ra},{ }^{232} \mathrm{Th}$ and ${ }^{40} \mathrm{~K}$ were $15.45 \pm 0.47$ ranging from $8.13 \pm 0.31$ to $33.57 \pm 0.83,18.00 \pm 0.55$, ranging from $10.59 \pm 0.33$ to $30.79 \pm 0.73$ and $215.73 \pm 4.29$ ranging from 
$124.00 \pm 2.53$ to $383.79 \pm 7.15$, respectively. It is clear that the concentrations of ${ }^{226} \mathrm{Ra},{ }^{232} \mathrm{Th}$ and ${ }^{40} \mathrm{~K}$ were below the critical values of 35,30 and 400 Bq. $\mathrm{kg}^{-1}$, respectively[13].

The values of $\mathrm{Ra}_{\mathrm{eq}}$ from the Wasteland soil ranged from $39.57 \pm 0.65$ to $87.16 \pm 1.28 \mathrm{~Bq} \cdot \mathrm{kg}^{-1}$ with an average of $57.80 \pm 0.98$ Bq. $\mathrm{kg}^{-1}$. The estimated values of $\mathrm{Ra}_{\mathrm{eq}}$ were below the world acceptable limit of $370 \mathrm{~Bq} \cdot \mathrm{kg}^{-1}$
[20]. When the average value was compared with those from other studies, the value of this study was lower than those measured in Ondo city, Southwestern Nigeria of 119.11 Bq. $\mathrm{kg}^{-1}$ [20].

The result of the outdoor absorbed dose rate ranged from $18.44 \pm 0.29$ to $40.86 \pm 0.57 \mathrm{nGy} \cdot \mathrm{h}^{-1}$ with an average of $27.00 \pm 0.44 \mathrm{nGy} \cdot \mathrm{h}^{-1}$. This value was found lower than the internationally acceptable value of $59 \mathrm{nGy} \cdot \mathrm{h}^{-1}$. [13].

Table (1): Activity Concentrations $\left({ }^{226} \mathrm{Ra},{ }^{232} \mathrm{Th}\right.$ and $\left.{ }^{40} \mathrm{~K}\right)$, Radium Equivalent Activity (Req) and Absorbed Dose Rate $\left(D_{R}\right)$ from Okakarara Wasteland Soils, Namibia

\begin{tabular}{|c|c|c|c|c|c|}
\hline \multirow[b]{2}{*}{ Sample ID } & \multicolumn{3}{|c|}{ Activity Concentrations $\left(\mathrm{Bq} \mathrm{kg}^{-1}\right)$} & \multirow{2}{*}{$\begin{array}{c}(\text { Req) } \\
\left(\text { Bq kg }^{-1}\right)\end{array}$} & \multirow{2}{*}{$\begin{array}{c}\left(D_{\mathbf{R}}\right) \\
\left(\mathbf{n G y} \cdot \mathbf{h}^{-1}\right)\end{array}$} \\
\hline & ${ }^{226} \mathbf{R a}$ & ${ }^{232} \mathrm{Th}$ & ${ }^{40} \mathbf{K}$ & & \\
\hline Ok-01 & $26.14 \pm 0.69$ & $14.63 \pm 0.54$ & $156.08 \pm 3.30$ & $59.08 \pm 1.07$ & $27.42 \pm 0.48$ \\
\hline Ok-02 & $8.13 \pm 0.31$ & $11.77 \pm 0.48$ & $194.23 \pm 3.93$ & $39.92 \pm 0.81$ & $18.96 \pm 036$ \\
\hline Ok-03 & $24.09 \pm 0.65$ & $11.36 \pm 0.47$ & $153.09 \pm 3.24$ & $52.12 \pm 0.97$ & $24.37 \pm 0.43$ \\
\hline Ok-04 & $12.00 \pm 0.40$ & $19.02 \pm 0.55$ & $233.38 \pm 4.60$ & $57.17 \pm 0.95$ & $26.76 \pm 0.43$ \\
\hline Ok-05 & $13.76 \pm 0.46$ & $30.79 \pm 0.73$ & $381.48 \pm 7.11$ & $87.16 \pm 1.27$ & $40.86 \pm 0.57$ \\
\hline Ok-06 & $11.15 \pm 0.38$ & $20.90 \pm 0.58$ & $242.10 \pm 4.75$ & $59.68 \pm 0.98$ & $27.87 \pm 0.44$ \\
\hline Ok-07 & $33.57 \pm 0.84$ & $11.69 \pm 0.44$ & $159.57 \pm 3.34$ & $62.57 \pm 0.78$ & $29.22 \pm 0.35$ \\
\hline Ok-08 & $10.28 \pm 0.36$ & $18.26 \pm 0.53$ & $217.92 \pm 4.34$ & $53.17 \pm 0.90$ & $24.87 \pm 0.40$ \\
\hline Ok-09 & $10.52 \pm 0.37$ & $19.85 \pm 0.55$ & $210.44 \pm 4.21$ & $55.11 \pm 0.93$ & $25.62 \pm 0.41$ \\
\hline Ok-10 & $11.15 \pm 0.38$ & $20.81 \pm 0.57$ & $219.66 \pm 4.37$ & $57.82 \pm 0.96$ & $26.88 \pm 0.43$ \\
\hline Ok-11 & $12.49 \pm 0.83$ & $19.56 \pm 0.64$ & $207.94 \pm 4.17$ & $56.47 \pm 1.28$ & $26.26 \pm 0.57$ \\
\hline Ok-12 & $13.36 \pm 0.43$ & $19.21 \pm 0.64$ & $204.20 \pm 4.11$ & $56.55 \pm 1.06$ & $26.29 \pm 0.47$ \\
\hline Ok-13 & $30.02 \pm 0.82$ & $19.35 \pm 0.65$ & $209.69 \pm 4.20$ & $73.84 \pm 1.28$ & $34.30 \pm 0.57$ \\
\hline Ok-14 & $10.10 \pm 0.36$ & $16.86 \pm 0.51$ & $203.71 \pm 4.10$ & $49.90 \pm 0.87$ & $23.34 \pm 0.39$ \\
\hline Ok-15 & $13.61 \pm 0.43$ & $15.96 \pm 0.50$ & $200.96 \pm 4.05$ & $51.91 \pm 0.89$ & $24.31 \pm 0.40$ \\
\hline Ok-16 & $13.67 \pm 0.44$ & $29.63 \pm 0.71$ & $383.97 \pm 7.15$ & $85.61 \pm 1.24$ & $40.22 \pm 0.56$ \\
\hline Ok-17 & $9.21 \pm 0.34$ & $13.70 \pm 0.45$ & $180.77 \pm 3.71$ & $42.72 \pm 0.78$ & $20.07 \pm 0.35$ \\
\hline Ok-18 & $14.88 \pm 0.41$ & $10.59 \pm 0.33$ & $124.00 \pm 2.53$ & $39.57 \pm 0.65$ & $18.44 \pm 0.29$ \\
\hline Minimum & $8.13 \pm 0.31$ & $10.59 \pm 0.33$ & $124.00 \pm 2.53$ & $39.57 \pm 0.65$ & $18.44 \pm 0.29$ \\
\hline Maximum & $33.57 \pm 0.83$ & $30.79 \pm 0.73$ & $383.97 \pm 7.15$ & $87.16 \pm 1.28$ & $40.86 \pm 0.57$ \\
\hline Average & $15.45 \pm 0.47$ & $18.00 \pm 0.55$ & $215.73 \pm 4.29$ & $57.80 \pm 0.98$ & $27.00 \pm 0.44$ \\
\hline $\begin{array}{c}\text { World } \\
\text { Average (13) }\end{array}$ & 35 & 30 & 400 & 370 & 59 \\
\hline
\end{tabular}


The results of Annual Effective Dose Equivalent (AEDE), Representative level index, The Annual Gonadal Dose Equivalent (AGDE), External Hazard index $\left(\mathrm{H}_{\mathrm{ex}}\right)$ and Excess Lifetime Cancer Risk (ELCR) of Okakarara Wasteland Soils were calculated as presented in Table 2.

The AEDE range from 0.02 to $0.05 \mathrm{mSv} \cdot \mathrm{y}^{-1}$ and average value was found to be $0.03 \mathrm{mSv} \cdot \mathrm{y}^{-1}$ for the wasteland soil. The average value of AEDE was found to be below the worldwide average of $0.48 \mathrm{mSv}$ (13).

The Annual Gonadal Dose Equivalent (AGDE) values for Wasteland Soils were in the range 129.29 to $291.31 \mu \mathrm{Sv} . \mathrm{y}^{-1}$ with an average of $190.89 \mu \mathrm{Sv} \mathrm{y}^{-1}$. This value was less than the world average value of 298 $\mu \mathrm{Sv} . \mathrm{y}^{-1}[21]$.
On the other hand, the Representative Level Index (RLI) was found to be in the range 0.29 to $0.65 \mathrm{~Bq} \mathrm{~kg}^{-1}$ with an average value of $0.43 \mathrm{~Bq} \mathrm{~kg}^{-1}$. Clearly, the RLI values obtained in the present work did not exceed the value of unity, which is the critical value. [22].

The results of the External Hazard Index $\left(\mathrm{H}_{\mathrm{ex}}\right)$ ranged from 0.11 to 0.24 with an average of 0.16 . The calculated results showed that all the values for $\mathrm{H}_{\mathrm{ex}}$ were lower than unity, which is the maximum permissible value by UNSCEAR [13], making the wasteland soil safe to the population in the area.

The excess lifetime cancer risk (ECLR) ranged from $0.79 \times 10^{-4}$ to $1.75 \times 10^{-4}$, with a mean of $1.16 \times 10^{-}$ ${ }^{4}$. This evaluated result was found to be lower than the world critical value of $2.9 \times 10^{-4}$ [23].

Table (2): Annual Effective Dose Equivalent (AEDE), Representative level index (RLI), The Annual Gonadal Dose Equivalent (AGDE), External Hazard index $\left(\mathrm{H}_{\mathrm{ex}}\right)$ and Excess Lifetime Cancer Risk (ELCR) Okakarara Wasteland Soils, Namibia.

\begin{tabular}{cccccc}
\hline $\begin{array}{c}\text { Sample } \\
\text { ID }\end{array}$ & $\begin{array}{c}(\mathbf{A E D E}) \\
\left(\mathbf{m S v} \cdot \mathbf{y}^{-1}\right)\end{array}$ & $\begin{array}{c}(\mathbf{R L I}) \\
\left(\mathbf{B q ~ k g}^{-1}\right)\end{array}$ & $\begin{array}{c}(\mathbf{A G D E}) \\
\left(\boldsymbol{\mu S v . \mathbf { y } ^ { - 1 }}\right)\end{array}$ & $\left(\mathbf{H}_{\text {ex }}\right)$ & $\begin{array}{c}(\mathbf{E L C R}) \\
\mathbf{x ~ 1 0}\end{array}$ \\
\hline Ok-01 & 0.03 & 0.42 & 191.08 & 0.16 & 1.18 \\
Ok-02 & 0.02 & 0.30 & 135.43 & 0.11 & 0.81 \\
Ok-03 & 0.03 & 0.38 & 170.11 & 0.14 & 1.05 \\
Ok-04 & 0.03 & 0.43 & 190.06 & 0.15 & 1.15 \\
Ok-05 & 0.05 & 0.65 & 291.31 & 0.24 & 1.75 \\
Ok-06 & 0.03 & 0.44 & 198.04 & 0.16 & 1.20 \\
Ok-07 & 0.04 & 0.45 & 202.82 & 0.17 & 1.25 \\
Ok-08 & 0.03 & 0.40 & 176.70 & 0.14 & 1.07 \\
Ok-09 & 0.03 & 0.41 & 181.76 & 0.15 & 1.10 \\
Ok-10 & 0.03 & 0.43 & 190.62 & 0.16 & 1.15 \\
Ok-11 & 0.03 & 0.42 & 185.84 & 0.15 & 1.13 \\
Ok-12 & 0.03 & 0.42 & 185.89 & 0.15 & 1.13 \\
Ok-13 & 0.04 & 0.53 & 239.68 & 0.20 & 1.47 \\
Ok-14 & 0.03 & 0.37 & 165.82 & 0.13 & 1.00 \\
Ok-15 & 0.03 & 0.38 & 172.03 & 0.14 & 1.04 \\
Ok-16 & 0.05 & 0.64 & 286.96 & 0.23 & 1.73 \\
Ok-17 & 0.02 & 0.32 & 142.62 & 0.12 & 0.86 \\
Ok-18 & 0.02 & 0.29 & 129.29 & 0.11 & 0.79 \\
\hline Minimum & $\mathbf{0 . 0 2}$ & $\mathbf{0 . 2 9}$ & $\mathbf{1 2 9 . 2 9}$ & $\mathbf{0 . 1 1}$ & $\mathbf{0 . 7 9}$ \\
\hline Maximum & $\mathbf{0 . 0 5}$ & $\mathbf{0 . 6 5}$ & $\mathbf{2 9 1 . 3 1}$ & $\mathbf{0 . 2 4}$ & $\mathbf{1 . 7 5}$ \\
\hline Average & $\mathbf{0 . 0 3}$ & $\mathbf{0 . 4 3}$ & $\mathbf{1 9 0 . 8 9}$ & $\mathbf{0 . 1 6}$ & $\mathbf{1 . 1 6}$ \\
\hline World & $\mathbf{0 . 4 8}$ & $\mathbf{1}$ & $\mathbf{2 9 8}$ & $\mathbf{1}$ & $\mathbf{2 . 9 0}$ \\
\hline Average [13] & & & & \\
\hline
\end{tabular}




\section{CONCLUSIONS}

Health Risk Assessment of Natural Radioactivity in Wasteland Soils of Okakarara was carried out with the help of a gamma-ray spectrometer. The average activity concentrations of ${ }^{226} \mathrm{Ra},{ }^{232} \mathrm{Th}$ and ${ }^{40} \mathrm{~K}$ were found to be $15.45 \pm 0.47,18.00 \pm 0.55$, and $215.73 \pm 4.29$, respectively. These values were below the acceptable concentrations of 35, 30 and $400 \mathrm{~Bq} \cdot \mathrm{kg}^{-1}$ [13]. The average $\mathrm{Ra}_{\text {eq }}$ value from the Wasteland soil was $57.80 \pm 0.98 \mathrm{~Bq} . \mathrm{kg}^{-1}$. In all the soil samples, $\mathrm{Ra}_{\mathrm{eq}}$ values were below the worldwide value of $370 \mathrm{~Bq} \cdot \mathrm{kg}^{-1}$ [20]. The absorbed dose rate in air (outdoor) because of terrestrial gamma rays was found to be $27.00 \pm 0.44 \mathrm{nGy} \cdot \mathrm{h}^{-1}$. This value was also lower than the world recommended average of $59 \mathrm{nGy} \cdot \mathrm{h}^{-1}$ [13]. It was also discovered that the average AEDE value was $0.03 \mathrm{mSv} . \mathrm{y}^{-1}$, which is less than the world recommended value of $0.48 \mathrm{mSv}$ [13], The Annual Gonadal Dose Equivalent (AGDE) value from the Wasteland soil was $190.89 \mu \mathrm{Sv} \cdot \mathrm{y}^{-1}$, and was found to be lower than the world critical value of $298 \mu \mathrm{Sv}^{-1} \mathrm{y}^{-1}$ [20]. The average values of RLI and $\mathrm{H}_{\mathrm{ex}}$ were found to be 0.43 and 0.16 , respectively. These indices were less than unity, thereby presenting no significant radiological concern to the people in the study area $[13,21]$. The average value of the excess lifetime cancer risk (ECLR) was found to be $1.16 \times 10^{-4}$ and lower than world average of $2.9 \times$ $10^{-4}$ by a factor of 0.4 [22]. From the results, it can be concluded that natural radioactivity at the wasteland area of Okakarara was not an issue of health concern.

\section{REFERENCES}

[1] Allisy, A. Henri Becquerrel (1996) The discovery of radioactivity", Becquerrel's Legacy: A Century of Radioactivity. Proceedings of a Conference, London: Nuclear Technology Publishing, pp. 3-10

[2] Santawamaitre, T. An Evaluation of the Level of Naturally Occurring Radioactive Materials in Soil samples along the Chao Phraya River Basin, $\mathrm{PhD}$ Thesis, University of Surrey: 2012.

[3] Radiation Protection Distance Learning Project, Australian Nuclear Science and Technology Organisation: International Atomic Energy Agency (IAEA): Austria. 2014.

[4] Radioactive Equilibrium: United States Environmental Protection Agency (USEPA). USA: 2009: http://www.epa.gov/rpdweb00/understand/ equilibrium.html. Accessed 20 September 2020.

[5] Biological Effects of Ionizing Radiation, HEW Publication (FDA) (2006) United States Food and Drug Administration (USFDA). 77-8004. USA.
[6] Nonstochastic effects of ionizing radiation, ICRP Publication No. 41. Oxford, Pergamon Press, (Annals of the ICRP 14, 3). International Commission of Radiological Protection (ICRP): 1984.

[7] Lee, G.F and Lee, J.A. Municipal solid waste landfills e Water quality issues. In Water encyclopaedia: Water quality and resource development (pp. 163e169). NJ: John Wiley: 2005.

[8] Senthilkumar R.D. and Narayanaswamy, R. (2016) Assessment of radiological hazards in the industrial effluent disposed soil with statistical Analyses. J. Radiat Res Appl Sci 9: 449- 456

[9] Ademola, A.K., Olaoye, M.A, and Abodunrin P.O. (2015) Radiological safety assessment and determination of heavy metals in soil samples from some waste dumpsites in Lagos and Ogun state, south-western, Nigeria, J .Radiat Res Appl Sci: 8: $148-153$

[10] Onjefu, S.A., Kgabi, N.A., Taole, S.H., Grant, C., and Antoine, J. (2017) Assessment of natural radionuclide distribution in shore sediment samples collected from the North Dune Beach, Henties Bay, Namibia: J. Radiat Res Appl Sci, 10: 301-306.

[11] Tufail M. (2012) Radium equivalent activity in the light of UNSCEAR report. Pakistan Institute of Engineering and Applied Sciences. Environ Monit Assess, 184: 5663-5667.

[12] Kocher, D.C., and Sjoreen, A.L (1985) Dose rate conversion factors for external exposure to photon emitters in soil. Health Phys, 48: 193-205.

[13] UNSCEAR (2000) United Nations Scientific Committee on the Effects of Atomic Radiation. Sources Effects and Risks of Ionizing Radiation, United Nations Report to the General Assembly, With Annexes: (UNSCEAR): New York, USA.

[14] ICRP (2008) International Commission of Radiological Protection. Recommendations of the, Annals of the International Commission of Radiological Protection (ICRP), ICRP Publication 103: Vol. 32, 2-4.

[15] UNSCEAR (2010) United National Scientific Committee on the Effects of Atomic Radiation. Sources and Effects of Ionizing Radiation: Report to the General Assembly, with scientific annexes vol 1 (United Nations, New York): 1-219.

[16] Najam, L.A., Tawfiq, N.F., Younis, S.A (2015) A Comparative study of the results of natural 
radioactivity and the associated radiation hazards of $\mathrm{Na}(\mathrm{Tl})$ and HPGe Detectors. Inter J. Recent Res Reveiw, 8, 1-7.

[17] Krieger R (1981) Radioactivity of construction materials, Betonwerk Fertigteil Tech 47: 468-473.

[18] Beretka, J., and Mathew P.J (1995) Natural radioactivity of Australian building materials, Industrial wastes and by-products: Health Phys, 48: 87-95

[19] Taskin, H., Karavus, M., Ay, P., Topuzoğlu, A., Hidiroglu, S, and Karahan, G., (2008) Radionuclide concentrations in soil and lifetime cancer risk due to gamma radioactivity in Kirklareli, Turkey. J. Environ $\quad$ Radioact, 100: 49-53. 10.1016/j.jenvrad.2008.10.012. https://www.researchgate.net/publication/22202978 3._Radionuclide_concentrations_in_soil_and_lifeti me_cancer_risk_due_to_gamma_radioactivity_in $\underline{\text { Kirklareli Turkey. Accessed } 21 \text { September } 2020}$
[20] Faweya, EB., Olowomofe, GO., Akande, HT., Faweya, O., Adesakin, GE., (2019) Evaluation of radon exhalation rate and excessive lifetime cancer risk in dumpsites in Ondo city South-western Nigeria: Int J. Rad Res 17(3): 379-382.

[21] OECD (1979) Organization for Economic Cooperation and Development. Exposure to radiation from the natural radioactivity in building materials. Report by a Group of Experts of the (OECD).

[22] Al-Kaabi, M.A, and Hmood A.N (2019) Study of the radiological doses in Karbala City: Inter J. of Radiat Res, Vol 10, No 1. DOI: 10.18869/acadpub.ijrr.17.1.171.

[23] Nasim, A., Sabiha, J, and Tufail, M. (2012) Enhancement of natural radioactivity in fertilized soil of Faisalabad, Pakistan. Environ Sci Pollut Res Int 19(8): 3327-3338. 